\title{
Barrie Carter, Ph.D.
}

Executive Vice President, Director of R\&D

Targeted Genetics Corp.

1100 Olive Way

Suite 100

Seattle, WA 98101

United States

Dr. Barrie Carter joined Targeted Genetics in August 1992 as Executive Vice President and Director, Research and Development. Prior to that time, Dr Carter was at the National Institutes of Health in Bethesda, MD for 22 years, where he was Chief of the Laboratory of Molecular and Cellular Biology in the National Institute for Diabetes and Digestive and Kidney Diseases. Barrie Carter received his B.S. (Hons) degree from the University of Otago, Dunedin, New Zealand and his Ph.D. in the Biochemistry Department of the University of Otago Medical School. He then spent a period of postdoctoral training at the Imperial Cancer Research Fund Laboratories in London, UK, before going to the National Institutes of Health in Bethesda. His long-term research interests are in molecular biology of viruses and the development of gene delivery vectors for gene therapy, and while at NIH he developed AAV vectors. He is an Affiliate Professor of Medicine at the University of Washington Medical School in Seattle. He currently serves on the Editorial Boards of Human Gene Therapy, Virology, and Current Research in Molecular Therapeutics. He also served previously on the Editorial Boards of The Journal of Virology, CRC Handbook on Parvoviruses, and Gene Therapy News Letter. 